JURNAL ILMIAH KEBIDANAN IMELDA

Vol.7, No.1, Maret 2021, pp. 30-35

ISSN: 2597-7180 (Online), 2442-8116 (Print)

\title{
ANALISIS UNSUR-UNSUR PEMBAGIAN PENGIMUNAN DASAR LENGKAP PADA BAYI DI PUSKESMAS SIMARIMBUN KOTA PEMATANGSIANTAR TAHUN 2020
}

\author{
Sondang ET Simanungkalit ${ }^{1}$, Eva Ratna Dewi ${ }^{2}$, Martaulina Sinaga ${ }^{3}$, Asnita Sinaga ${ }^{4}$ \\ STIKes Mitra Husada Medan, Indonesia
}

\begin{tabular}{l}
\hline \hline Article Info \\
\hline Article history: \\
Received Jan 26, 2021 \\
Revised Feb 19, 2021 \\
Accepted Mar 13, 2021
\end{tabular}

\section{Keywords:}

Distribution of Imposition

Vaccines

Supporting Elements

\begin{abstract}
The distribution of storage is a form of health intrusion that is very effective in reducing the mortality rate for infants and toddlers. With the distribution of various diseases such as hepatitis $\mathrm{B}$, tuberculosis, polio, diphtheria, pertussis, tetanus, and others can be prevented. The importance of the distribution of Pengimunan can be seen from the number of children under five who died due to diseases that can be prevented by Pengimunan This type of research is carried out by means of descriptive observational research with a retrospective approach. This research used a cross-sectional design by measuring the variables at a certain time, each subject was observed only once and the measurement of the subject variables was carried out at a certain time of examination and no follow-up was carried out on the data collection where the dependent variable was the Complete Basic Infection Distribution in Infants and The independent variables are Mother Education, Mother's Understanding, Mother Work, Number of Children in the Family and Family Support, where the researchers determined that as many as 64 mothers who had babies aged 0-12 months in the working area of the Simarimbun Community Health Center Pematangsiantar as mothers After doing the research, the results obtained from 64 mothers at the level of education, the chi square test of Asymp.Sig. (2-sided) P0.035, understanding of mothers, Asymp.Sig. (2-Sided) 0.088, Mother's Occupation with Asymp.Sig. (2-sided) 0.322 , the number of children with the Asymp value. Sig. (2 - Sided) 0.168, family support value Asymp. Sig. (2-Sided) 0.159. Of all the independent variables, there are no all elements that have a relationship or influence at the level of completeness of the sending of the baby, only the elements of the level of mother's education and the element of mother's understanding have something to do with the element of the mother's education, while the elements of mother's work, number of children and family support have nothing to do and have nothing The result of this research is only based on the assessment of the value and Asymp.Sig (2Sided) alone, it cannot be based on the results of the Expecteed count.
\end{abstract}

This is an open access article under the CC BY-SAlicense.
Corresponding Author:
Sondang ET Simanungkalit,
Program Studi S-1 Kebidanan,
STIKes Mitra Husada Medan,
Jl. Pintu Air IV Pasar 8 Kelurahan Kwala Berkala Kecamatan Medan Johor, Medan - Sumatera Utara.
Email: sondangsimanungkalit85@gmail.com




\section{INTRODUCTION}

Pembagian Pengimunan merupakan bentuk intrusi kesehatan yang sangat ampuh dalam menurunkan angka mortalitas bayi dan balita. Dengan pembagian Pengimunan berbagai penyakit seperti hepatitis B, tuberkulosis, polio, difteri, pertusis, tetanus, dan lainnya dapat dicegah. Pentingnya pembagian Pengimunan dapat dilihat dari banyaknya balita yang meninggal akibat penyakit yang dapat dicegah dengan Pengimunan yang diperkirakan 2 hingga 3 juta mortalitas tiap tahunnya Lingkup Pengimunan campak di Indonesia adalah sebesar $84 \%$ dan merupakan wilayah dalam kategori sedang (Kemenkes, 2016).

Menurut WHO sekitar 1,5 juta anak mengalami mortalitas tiap tahunnya karena penyakit yang dapat dicegah dengan Pengimunan. Pada Tahun 2018, terdapat kurang lebih 20 juta anak tiada mendapatkan Pengimunan lengkap dan bahkan ada anak yang tiada mendapatkan Pengimunan sama sekali.Indonesia termasuk salah satu wilayah dengan jumlah anak yang tiada mendapatkan Pengimunan lengkap cukup banyak. Situasi ini telah berdampak pada munculnya Kejadian Luar Biasa (KLB) penyakit yang dapat dicegah dengan Pengimunan yaitu difteri, campak, dan polio.

Untuk mewujudkan derajat kesehatan komunitas yang setinggi-tingginya diperlukan upaya untuk mencegah terjadinya suatu penyakit melalui pembagian Pengimunan, bahwa untuk melaksanakannya perlu mengatur ketentuan mengenai penyelenggaraan Pengimunan. Pengimunan adalah suatu upaya untuk menimbulkan /meningkatkan kekebalan seseorang secara aktif terhadap suatu penyakit sehingga bila suatu saat terpajan dengan penyakit tersebut tiada akan sakit atau hanya mengalami sakit ringan (Kemenkes, 2017).

Pelaksanaan Pengimunan dapat mencegah 1-2 juta mortalitas setiap tahun akibat penyekit Difteri, Pertusis dan Tetanus. Namun pada tahun 2014 terdapat 18,7 juta bayi diseluruh dunia yang tiada mendapatkan Pengimunan DPT3 dan lebih dari 60\% anak tersebar di Republik Demokrasi Kongo, Eutopia, India, Indonesia, Irak, Nigeria, Pakistan, Filipina, Uganda dan Afrika Selan (WHO 2015).

Pada tahun 2015 lingkup Pengimunan Dasar Lengkap (IDL) adalah sebesar 86,8\% yang harus ditingkatkan menjadi 93\% di tahun 2019. Begitu pula dengan Universal Child Immunization (UCI) desa yang kini mencapai 82,9\% harus ditingkatkan menjadi $92 \%$ di tahun 2019. Oleh karena itu, dari 194 wilayah anggota WHO, 65 diantaranya memiliki lingkup Pengimunan Difteri, Pertusis, Tetanus dibawah 90\% termasuk Indonesia (Pusat data dan informasi PERSI, 2015). Kebijakan Pengimunan nasional menurut RPJMN-Kesehatan tahun 2015-2019 adalah tercapainya lingkup IDL sebesar 93\% pada usia 0-11 bulan dengan rincian tahun 2015 diharapkan tercapai 91\%, tahun 2016 sebesar 91,5\%, tahun 2017 sebesar 92\%, tahun 2018 sebesar 92,5\% dan tahun 2019 mencapai 93\% (Kemenkes RI, 2015).

Lima tahun terakhir program Pengimunan di Indonesia tiada mengalami perkembangan yang signifikan. Hasil Riset Kesehatan Dasar 2018 Kementrian Kesehatan RI memperlihatkan lingkup Pengimunan Dasar Lengkap (IDL) pada anak usia 12-23 bulan menurun dari 59,2\% di tahun 2013 menjadi sebesar 57,9\% di tahun 2018. Hal ini berarti dari 6 juta anak usia 12-23 bulan, hanya sekitar 2,5 juta yang telah mendapat Pengimunan dasar lengkap. Sebaliknya, anak yang di Pengimunan namun tiada lengkap meningkat dari 32,1\% menjadi 32,9\% dalam periode waktu yang sama (Ndoen, 2018).

Berdasarkan Profil Kesehatan Sumatera Utara tahun 2014, lingkup IDL kabupaten/kota tertinggi di Sumatera Utara adalah Kabupaten Dairi yakni data sebesar 106,92\% dan yang terendah adalah Kabupaten Nias Utara yakni data sebesar 8,7\% (Dinkes Sumatera Utara, 2015). Sasaran Pengimunan MR di Provinsi Sumatera Utara sebanyak 4.291.857 anak. Sampai dengan Oktober 2018 lingkup Pengimunan dilaporkan mencapai 2.084.997 anak (48,60\%). Kemenkes RI telah menetapkan target harian per Oktober 2018 di dapat data sebesar 81,2\% maka dari 33 kabupaten/kota provinsi Sumatera Utara, baru 9 kabupaten yang telah mencapai target yaitu yang menjadi urutan yang pertama adalah Toba Samosir (101,90\%), urutan kedua Samosir (100\%), urutan ketiga Humbang Hasundutan (98,15\%), urutan keempat Dairi $(97,84 \%)$, urutan kelima Tapanuli Utara $(89,24 \%)$, urutan keenam Nias $(88,37 \%)$, urutan ketujuh Karo $(87,21 \%)$, urutan kedelapan Simalungun (85,54\%) dan urutan kesembilan Pematang Siantar (83,29\%).

Data Riset Kesehatan Dasar tahun 2018 memperlihatkan lingkup Pengimunan Dasar Lengkap (IDL) mencapai 57,9\%, Pengimunan tiada lengkap sebesar 32,9\% dan 9,2\% tiada di Pengimunan. Pencapaian indikator program Pengimunan tahun 2018 dengan target 90\% pencapaiannya 61,9\% (Kemenkes 2019).

Campak merupakan 10 penyakit terbesar penyebab mortalitas anak usia 29 hari sampai 4tahun berdasarkan Riskesdas tahun 2007. Lingkup Pengimunan campak mengalami kecenderungan penurunan selama periode 2013 yaitu sebesar (97,8\%), 2015 (92,3\%), namun kejadian Kejadian Luar Biasa (KLB) campak memperlihatkan hal sebaliknya, yakni terjadi penurunan pada tahun 2013 yaitu (862 kasus) dan 2015 (831 kasus). Fenomena tersebut memperlihatkan adanya hubungan negatif antara lingkup Pengimunan campak dengan jumlah kasus campak (Kemenkes, 2016).

Berdasarkan profil Kesehatan Indonesia tahun 2018 pencapaian Pengimunan dasar lengkap terendah yaitu Papua $(30,4 \%)$ dan tertinggi Kepulauan Riau $(102,4 \%)$, Sumatera Utara pencapaian Pengimunan dasar lengkap (68,8\%) (Riskesdas, 2019). Berdasarkan profil Kesehatan Sumatera Utara 2016 hanya ada 2 daerah dari 33 daerah yang 100\% desanya telah mencapai UCI yaitu Kota Medan dan Kabupaten Pakpak Bharat. 
Sedangkan, lima daerah terendah pencapaian UCI nya di Sumatera Utara adalah Nias Selatan $(8,7 \%)$, Kota Padang Sidempuan (19,9\%), Padang Lawas (36,3\%), Kota Pematangsiantar (45,3\%), dan Tapanuli Tengah $(54,4 \%)$.

Berdasarkan profil Kesehatan Pematangsiantar pada tahun 2019 Kota Pematangsiantar memiliki 8 Kecamatan, 19 Puskesmas dan 53 Kelurahan. Ada 8 Puskesmas terendah di Kota Pematangsiantar yaitu Puskesmas Tomuan (88,6\%), Puskesmas Kartini (92,5\%), Puskesmas Aek nauli (88,4\%), Puskesmas Rami (81,6\%), Puskesmas Gurilla (87,4\%), Puskesmas Bah Kapul (80,9\%), Puskesmas Parsoburan (81,8\%) dan Puskesmas Simarimbun (85\%).

Berdasarkan data yang diperoleh target pembagian Pengimunan dasar lengkap pada bayi di Kota Pematangsiantar pada tahun 2019 (90,1\%). Berdasarkan data yang di peroleh dari Puskesmas Simarimbun lingkup Pengimunan dasar lengkap (IDL) tahun 2019 (85\%), lingkup Pengimunan HBO (63,1\%), lingkup Pengimunan BCG $(94,7 \%)$, lingkup Pengimunan DPT/HB/HIB3 $(87,2 \%)$, lingkup Pengimunan POLIO 4 (76,8\%), lingkup Pengimunan IPV (87,8\%), lingkup Pengimunan MR (89,5\%).

\section{RESEARCH METHOD}

Jenis riset ini dilakukan dengan riset observasional bersifat deskriptif dengan pendekatan retrospektif. Riset ini menggunakan desain cross-sectional. Dalam riset cross-sectional peneliti mengadakan pengukuran peubah pada satu saat tertentu tiap subjek hanya diobservasi satu kali dan pengukuran peubah subjek dilakukan pada saat pemeriksaan tertentu dan tiada mengadakan tindak lanjut terhadap pengukuran yang dilakukan. Dalam riset ini yang dijadikan populasi kasus adalah seluruh ibu yang memiliki bayi usia 012 bulan Tahun 2019 yang bertempat tinggal di Kelurahan Simarimbun dan Tong Marimbun di Puskesmas Simarimbun Kota Pematangsiantar yaitu 171 orang. Sampel dalam riset ini adalah ibu yang memiliki bayi usia 0 sampai 12 bulan yang datang ke posyandu di wilayah kerja Puskesmas Perawatan Tanjung Seloka untuk mengadakan Pengimunan bayinya sebanyak 64 orang di wilayah kerja Puskesmas Simarimbun Kota Pematangsiantar sebagai ibu. Riset ini dilaksanakan di posyandu Puskesmas Simarimbun Kota Pematangsiantar, Riset dilakukan selama 2 Minggu mulai tanggal 22 Juni 2020 sampai 4 Juli 2020.

Pengumpulan Data dengan Data primer merupakan data yang diperoleh dengan cara mengadakan wawancara terhadap ibu menggunakan kuesioner untuk mendapatkan data tentang unsur-unsur yang berhubungan dengan pembagian Pengimunan dasar lengkap pada bayi di Puskesmas Simarimbun yang meliputi tingkat pendidikan ibu bayi, tingkat pemahaman ibu bayi, status pekerjaan ibu bayi, jumlah anak dalam keluarga, keterjangkauan ketempat pelayanan Pengimunan dan dukungan keluarga tehadap Pengimunan. Dan Data sekunder dalam riset ini antara lain: data lingkup Pengimunan dasar pada bayi yang diperoleh dari Dinas Kesehatan, data bayi yang menjadi sasaran Pengimunan dari Puskesmas Simarimbun dan data dari Kartu Menuju Sehat. Analisis data merupakan bagian penting dari suatu riset, adapun Langkah. Analisis univariat ini dilakukan terhadap tiap peubah dari hasil riset.

Analisis univariat ini berupa distribusi frekuensi dan presentase tiap peubah pendidikan ibu bayi, tingkat pemahaman ibu bayi, status pekerjaan ibu bayi, jumlah anak dalam keluarga, keterjangkauan ketempat pelayanan Pengimunan dan dukungan keluarga terhadap pembagian Pengimunan dasar lengkap pada bayi. Analisis bivariat adalah analisi yang dilakukan terhadap dua peubah yang diduga berhubungan atau berkolerasi (Notoadmodjo, 2012). Analisis ini digunakan untuk mengetahui hubungan antara peubah bebas dengan peubah terikat secara sendiri sendiri dimana analisis ini menggunakan uji chi square untuk menguji mengenai ada atau tiadanya hubungan antara peubah bebas dengan peubah terikat.

\section{RESULTS AND ANALYSIS}

\subsection{Hasil}

Setelah dilakukan riset maka didapat hasil dari 64 ibu dapat dilihat pada tabel 1, 16 ibu dengan tingkat Pendidikan SD-SMP dan 48 ibu dengan tingkat Pendidikan SMU/SMK- Tingkat Lanjutan Atas, dimana dengan tingkat Pendidikan SD-SMP anak balita yang dengan Pengimunan lengkap sebanyak 16 anak (100\%). Dan ibu dengan tingkat Pendidikan SMU/SMK - Tingkat Lanjutan Atas dari 48 ibu sebanyak 37 anak balita mendapatkan Pengimunan lengkap (77,1\%) dan 11 anak dengan Pengimunan tiada lengkap $(17,2 \%)$.

Tabel 1. Hubungan Tingkat Pendidikan dengan Pembagian Pengimunan Dasar Lengkap Pada Bayi Di Puskesmas Simarimbun Kota Pematangsiantar

\begin{tabular}{lccccccc}
\hline \multirow{2}{*}{ Tingkat Pendidikan } & \multicolumn{2}{c}{$\begin{array}{c}\text { Pengimunan } \\
\text { Lengkap }\end{array}$} & \multicolumn{2}{c}{$\begin{array}{c}\text { Pengimunan } \\
\text { Tiada Lengkap }\end{array}$} & \multicolumn{2}{c}{ Jumlah } & \multirow{2}{*}{ Signifikan } \\
\cline { 2 - 8 } & $\mathbf{N}$ & $\mathbf{\%}$ & $\mathbf{N}$ & $\mathbf{\%}$ & $\mathbf{N}$ & $\mathbf{\%}$ & \\
\hline Rendah (SD-SMP) & 16 & 100 & 0 & 0 & 16 & 100 & $\mathrm{P}=0.035$ \\
\hline Tinggi (SMU-Perguruan Tinggi) & 37 & 77,1 & 11 & 22,9 & 48 & 100 & \\
\hline
\end{tabular}


Pada hasil tingkat pemahaman ibu, penulis mendapatkan hasil dari 64 ibu, sebanyak 26 ibu dengan pemahaman baik dimana 19 bayi $(73,1 \%)$ mendapatkan Pengimunan yang lengkap dan 7 bayi $(26,9 \%)$ tiada mendapatkan Pengimunan yang lengkap dan sebanyak 38 ibu dengan tingkat pemahaman cukup dimana 34 bayi $(89,5 \%)$ mendapatkan Pengimunan yang lengkap dan 4 bayi $(10,5 \%)$ tiada mendapatkan Pengimunan yang lengkap.

Tabel 2. Hubungan Tingkat Pemahaman Ibu dengan Pembagian Pengimunan Dasar Lengkap Pada Bayi Di

\begin{tabular}{cccccccc}
\multicolumn{7}{c}{ Puskesmas Simarimbun Kota Pematangsiantar } \\
\cline { 1 - 8 } Tingkat Pemahaman & $\begin{array}{c}\text { Pengimunan } \\
\text { Lengkap }\end{array}$ & $\begin{array}{c}\text { Pengimunan } \\
\text { Tiada Lengkap }\end{array}$ & Jumlah & \multirow{2}{*}{ Signifikan } \\
\cline { 2 - 8 } & $\mathbf{N}$ & $\mathbf{\%}$ & $\mathbf{N}$ & $\mathbf{\%}$ & $\mathbf{N}$ & $\mathbf{\%}$ & \\
\hline Baik = 76-100 \% Benar & 19 & 73.1 & 7 & 26.9 & 26 & 100 & $\mathrm{P}=0,088$ \\
\hline Cukup = 51-75 \%Benar & 34 & 89.5 & 4 & 10.5 & 38 & 100 & \\
\hline
\end{tabular}

Pada hasil tingkat Pekerjaan Ibu penulis mendapatkan hasil dari 64 ibu sebanyak 26 ibu yang bekerja, 23 bayi yaitu (88,5\%) mendapatkan Pengimunan yang lengkap dan 3 bayi yaitu $(11,5 \%)$ yang tiada lengkap Pengimunannya, dan dari 38 ibu yang tiada bekerja ada sebanyak 30 bayi yaitu (78,9\%) yang mendapat Pengimunan yang lengkap dan 8 bayi yaitu $(21,1 \%)$ yang tiada lengkap Pengimunannya.

Tabel 3. Hubungan Pekerjaan Ibu dengan Pembagian Pengimunan Dasar Lengkap Pada Bayi Di Puskesmas Simarimbun Kota Pematangsiantar

\begin{tabular}{lccccccc}
\hline \multirow{2}{*}{ Pekerjaan } & \multicolumn{2}{c}{$\begin{array}{c}\text { Pengimunan } \\
\text { Lengkap }\end{array}$} & \multicolumn{2}{c}{ Pengimunan } & Jumlah & \multirow{2}{*}{ Signifikan Lengkap } \\
\cline { 2 - 7 } & $\mathbf{N}$ & $\mathbf{\%}$ & $\mathbf{N}$ & $\mathbf{\%}$ & $\mathbf{N}$ & $\mathbf{\%}$ & \\
\hline Bekerja & 23 & 88,5 & 3 & 11,5 & 26 & 100 & $\mathrm{P}=0,322$ \\
\hline Tiada Bekerja & 30 & 78,9 & 8 & 21,1 & 38 & 100 & \\
\hline
\end{tabular}

Dari 64 ibu yang ada, ibu yang memiliki anak 1 sebanyak 8 ibu dimana tingkat kelengkapan Pengimunan sebanyak 8 bayi (100\%) dan ibu yang memiliki anak lebih dari 1 sebanyak 56 ibu, dengan bayi yang lengkap Pengimunannya sebanyak 45 bayi $(80,4 \%)$ dan 11 bayi $(19,6 \%)$ yang tiada lengkap imunisasinya.

Tabel 4. Hubungan Jumlah Anak dengan Pembagian Pengimunan Dasar Lengkap Pada Bayi Di Puskesmas Simarimbun Kota Pematangsiantar

\begin{tabular}{|c|c|c|c|c|}
\hline \multirow[t]{2}{*}{ Anak } & $\begin{array}{c}\text { Pengimunan } \\
\text { Lengkap }\end{array}$ & $\begin{array}{l}\text { Pengimunan } \\
\text { Tiada Lengkap }\end{array}$ & Jumlah & \multirow[t]{2}{*}{ Signifikan } \\
\hline & $\%$ & $\%$ & $\%$ & \\
\hline Jumlah anak 1 & 100 & 0 & $\begin{array}{ll}8 & 100 \\
\end{array}$ & $\mathrm{P}=0,168$ \\
\hline Jumlah anak > & 80,4 & 19,6 & 100 & \\
\hline
\end{tabular}

Dari hasil riset untuk Unsur dukungan keluarga, dari keseluruhan ibu yakni sebanyak 64 ibu sebanyak 59 ibu mendapat dukungan dari keluarga dimana 50 bayi $(84,7 \%)$ mendapat Pengimunan yang lengkap dan 9 bayi $(15,3 \%)$ tiada lengkap Pengimunannya, sedangkan untuk 5 ibu yang tiada mendapat dukungan keluarga, 3 bayi (60\%) mendapatkan Pengimunan yang lengkap dan 2 bayi (40\%) tiada lengkap Pengimunannya.

Tabel 5. Hubungan Dukungan Kelaurga dengan Pembagian Pengimunan Dasar Lengkap Pada Bayi Di Puskesmas Simarimbun Kota Pematangsiantar

\begin{tabular}{lccccccc}
\hline Dukungan Keluarga & \multicolumn{2}{c}{$\begin{array}{c}\text { Pengimunan } \\
\text { Lengkap }\end{array}$} & \multicolumn{2}{c}{$\begin{array}{c}\text { Pengimunan } \\
\text { Tiada Lengkap }\end{array}$} & Jumlah & \multirow{2}{*}{ Signifikan } \\
\cline { 2 - 7 } & $\mathbf{N}$ & $\mathbf{\%}$ & $\mathbf{N}$ & $\mathbf{\%}$ & $\mathbf{N}$ & $\mathbf{\%}$ & \\
\hline Mendukung & 50 & 84,7 & 9 & 15,3 & 59 & 100 & P $=0,159$ \\
\hline Tiada Mendukung & 3 & 60 & 2 & 40 & 5 & 100 & \\
\hline
\end{tabular}

\subsection{Pembahasan}

Tingkat Pendidikan ibu Dari hasil yang didapat dengan uji chi square nilai Asymp. Sig. (2-sided) 0.035 dimana nilai tersebut $<0,10$ (Tingkat Kepercayaan 10\%) atau berdasarkan person chi square dimana value 4,428 > 2,706 (sesuai daftar Tabel Chi square) maka penulis asumsikan bahwa tingkat Pendidikan Ibu ada hubungannya dengan unsur pembagian Pengimunan pada bayi dimana seorang ibu dapat memelihara dan mendidik anaknya dengan baik apabila dia sendiri berpendidikan, dengan kata lain semakin tinggi tingkat Pendidikan ibu maka semakin baik tumbuh kembang sianak khususnya dalam aspek pembagian Pengimunan yang lengkap. 
Tingkat Pengetahuan Ibu pada tabel chi square nilai Asymp.Sig. (2-Sided) 0,088<0,10, dan person chi square 2.916>2.706 maka dapat disimpulkan bahwa unsur tingkat pemahaman ibu ada hubungannya dengan pembagian Pengimunan pada bayi dimana bahwa pemahaman merupakan hasil dari penginderaan terhadap objek tertentu, dalam hal ini penulis menemukan fakta dari wawancara dan hasil kuesioner bahwa ibu yang aktif dalam kegiatan Kesehatan seperti posyandu akan lebih bersifat terbuka mengenai pembagian Pengimunan dan efek sampingnya daripada ibu yang tiada mau tahu atau perduli dengan aspek kesehatan ibu dan anak.

Tingkat Pekerjaan Ibu Dari hasil yang didapatkan dari rumus chi square Asymp.Sig. (2-sided) 0,322> 0.10 dan Pearson Chi Square $0.982<2,706$, dari data tersebut bisa dikatakan tiada ada hubungan antara unsur ibu yang bekerja ataupun tiada bekerja dengan lengkap atau tiada lengkapnya Pengimunan pada bayi, dalam hal ini penulis mendapatkan suatu hasil dari riset bahwa tiada selamanya ibu yang bekerja menjadi kurang perhatian pada anaknya khususnya dalam hal pemberia Pengimunan. Hasil dari riset yang penulis lakukan justru berbanding terbalik dari teoritis yang mengatakan bahwa jika ibu bekerja maka akan berkurang kesempatan waktu dan perhatian untuk membawa bayinya ketempat pelayan Pengimunan, sehingga akan mengakibatkan bayinya tiada mendapatkan pelayanan Pengimunan.

Faktor Jumlah anak, Adapun data sesuai dengan chi square, nilai Asymp. Sig. (2 - Sided) 0,168>0,10 dan Pearson chi square $1898<2706$, maka dapat disimpulkan bahwa unsur anak tiada ada hubungannya dengan lengkap atau tiadanya Pengimunan pada anak. Dalam hal ini penulis bisa mengasumsikan bahwa unsur ini tiada begitu relevan untuk dijadikan suatu peubah defenden dimana sesuai data ibu terdapat perbandingan yang signifikan antara ibu yang memiliki jumlah anak hanya satu (8 anak) dengan ibu yang memiliki jumlah anak lebih dari satu (56 anak). Dukungan Dari Keluarga, dari data chi square untuk Asymp.Sig. (2-Sided) 0,159 > 0,10, pearson Chi Square 1,983 < 2,706, berarti tiada ada hubungan unsur dukungan keluarga terhadap kelengkapan Pengimunan pada bayi, penulis berasumsi tingkat dukungan keluarga tiada begitu berpengaruh dimana pada masa sekarang ini siapapun dapat mengakses informasi lewat jejaring sosial dan ibu-ibu diwilayah kerja penulis tiada lagi terikat dengan segala sesuatu yang harus mendapatkan izin dari suami atau keluarga baru bisa dikerjakan atau dilakukan seperti pembagian Pengimunan pada anak.

\section{CONCLUSION}

Selama mengadakan riset ini ada beberapa kesimpulan dan pemahaman yang semakin dapat penulis pahami didalam menjalani proses demi proses riset yakni:

1. Dari semua peubah bebas tiada semua unsur memiliki hubungan atau mempengaruhi pada tingkat kelengkapan Pengimunan pada bayi, hanya unsur Tingkat Pendidikan Ibu dan Unsur Pemahaman Ibu yang ada hubungannya dengan Pengimunan pada bayi sedangkan Unsur Pekerjaan Ibu, Jumlah anak, dan Dukungan Keluarga tiada ada hubungannya dan tiada mempengaruhi kelengkapan Pengimunan pada bayi.

2. Hasil dari riset ini hanya berdasarkan penilaian dari nilai value dan Asymp.Sig (2-Sided) saja, tiada bisa berdasarkan hasil Expecteed count dimana pada setiap tabel chi square Dibagian bawah tabel output ChiSquare Tests terdapat keterangan "1 cells $(25,0 \%)$ have expected count less than 5. The minimum expected count is 2,75. (tabel Chi Square Tingkat Pendidikan) yang berarti bahwa asumsi penggunaan uji chi square dalam riset ini belum memenuhi syarat. Sebab tiada ada sel yang memiliki frekuensi harapan di atas 5 dan frekuensi harapan terendah adalah sebesar 2,75. Sementara jika asumsi atau persyaratan uji chi square untuk riset tiada terpenuhi, maka pengambilan keputusan untuk uji hubungan berpedoman pada nilai atau angka yang terdapat pada hasil Pearson Chi Square.

3. Perlu adanya pemahaman pada setiap peneliti yang akan mengadakan riset untuk lebih memahami konseptual suatu riset dimana setiap riset yang kita lakukan akan menjadi acuan atau landasan bagi peneliti selanjutnya untuk menghasilkan suatu riset yang lebih akurat.

4. Sebagai tenaga Kesehatan kita harus belajar untuk mampu mengadakan riset riset berikutnya dalam bidang Kesehatan terutama saat kita melaksanakan tugas kita di lingkungan pekerjaan.

\section{REFERENCES}

Depkes Provinsi Sumatera Utara. 2019. Modul Pelaksanaan Pengimunan Rutin Bagi Petugas Pengimunan. Sumatera Utara: DEPKES.

Dwi Maryanti, S.SIT, Dkk. 2011. Buku Ajar Neonatus, Bayi dan Balita. Jakarta: Trans Info Media.

Fitriani, E. 2011. Unsur -Unsur Yang Berhubungan Denagan Kelengkapan Pengimunan Dasar Pada Bayi Di Desa Kumpurejo Kecamatan Argomulyo Kota Salatiga. Skripsi.

Fitriani, E. 2017. Unsur Yang Mempengaruhi Ketepatan Pembagian Pengimunan Dasar Di Wilayah Kerja Puskesmas Perawatan Tanjung SelokaKabupaten Kotabaru. Skripsi.

Friedman T, 2010. Buku Ajar Keperawatan Keluarga Cetakan Ke 8. Jakarta: Rineka Cipta. 
Juliana Munthe. 2019. Buku Ajar Asuhan Kebidanan Berkesinambungan. Jakarta: Trans Info Media

Kementerian Kesehatan RI. 2016. Buku Panduan Posyandu Menuju Keluarga Sadar Gizi. Jakarta: Kementerian Kesehatan.

Maryunani, A. 2016. Asuhan Neonatus Bayi, Balita dan Anak Pra Sekolah. Bogor: IN Media.

Notoatmodjo, S. 2012. Metodologi Riset Kesehatan (edisi revisi cetakan pertama). Jakarta: Rineka Cipta.

Nurul, I. 2018. Analisis Pelaksanaaan Program Pengimunan Dasar Lengkap (IDL) Pada Bayi Di Puskesmas Kota Semarang. Jurnal Kesehatan Komunitas (e-jurnal) Vol. 6, No 5. Hal. 86-94.

Riza, Y. 2018. Analisis Unsur Kelengkapan Pengimunan Dasar Pada Balita Di Wilayah Kerja Puskesmas Cempaka Banjarmasin Tahun 2018. MPPKI. Vol. 1, No 3. Hal 75-80.

\section{BIOGRAPHIES OF AUTHORS}

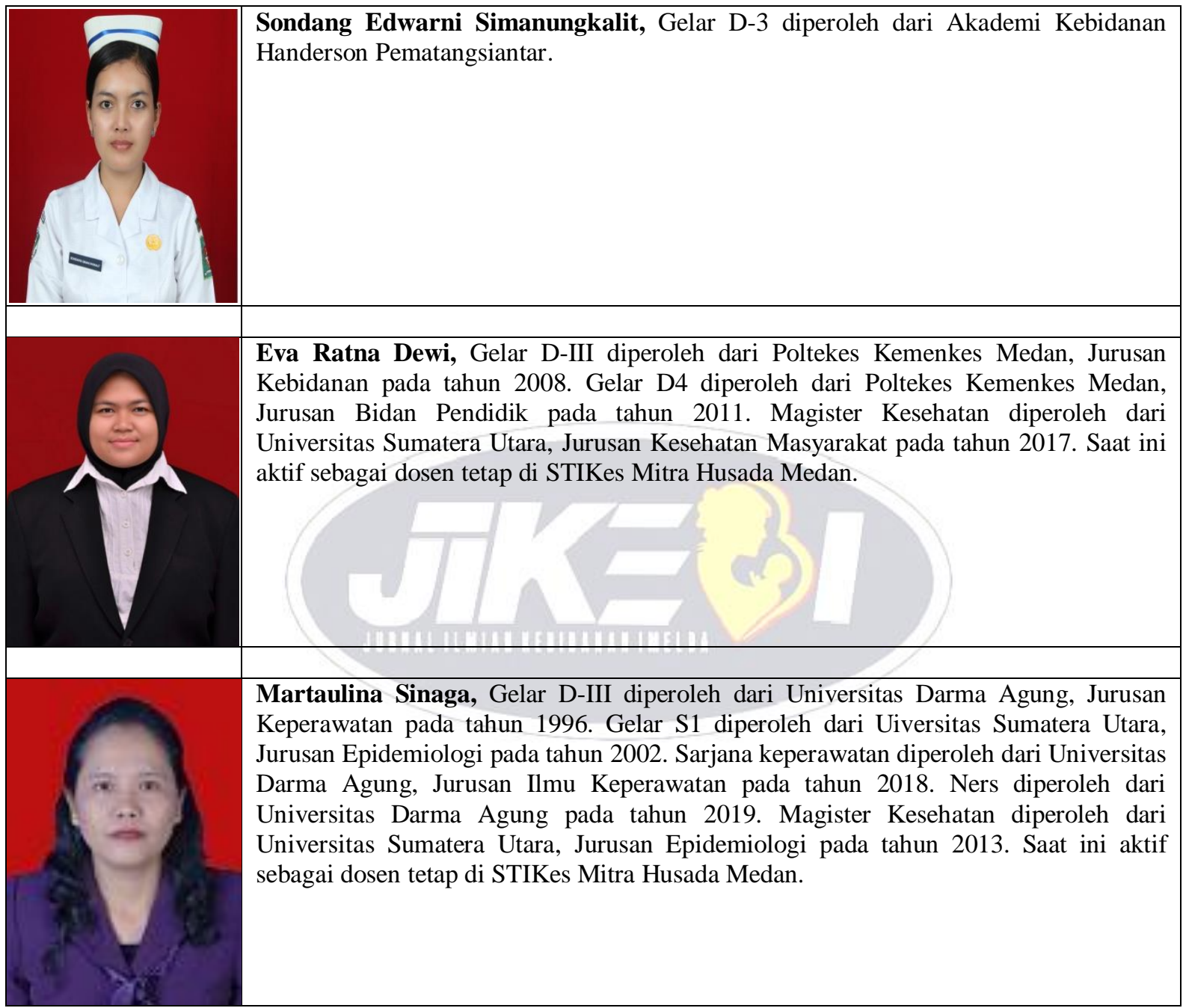

